\title{
BLOCK RESECTION OF LUMBAR OSTEOBLASTOMA. PRESENTATION OF A CASE AND BIBLIOGRAPHICAL UPDATE
}

\author{
RESSECÇÃO EM BLOCO DO OSTEOBLASTOMA LOMBAR. APRESENTAÇÃO DE UM CASO \\ E ATUALIZAÇÃO BIBLIOGRÁFICA

\section{RESECCIÓN EN BLOQUE DE OSTEOBLASTOMA LUMBAR. PRESENTACIÓN DE UN CASO Y ACTUALIZACIÓN BIBLIOGRÁFICA} \\ Pedro luis Bazán, ${ }^{1,2}$ Richard Avero Gonzalez, ${ }^{1,3}$ Nicolás Maximiliano Cicciolı, 1,2 Enrique Alcides Casco, ${ }^{1,4}$ Álvaro Enrique Borri, ${ }^{1,2}$ Martín Medina ${ }^{1,2}$ \\ 1. HIGA San Martín, La Plata, Buenos Aires, Argentina. \\ 2. Hospital Italiano La Plata, La Plata, Buenos Aires, Argentina. \\ 3. Facultad de Ciencias Médicas - Universidad Nacional de La Plata. Buenos Aires, Argentina. \\ 4. AOSpine Latin America Fellowships.
}

\begin{abstract}
Objective: To present the clinical case and update the bibliography. Methods: A male patient, 24 years of age, sought treatment for right lumbosciatalgia of 3 years of evolution with topography L5 and motor deficit (M4). The radiograph showed a radiopaque lesion between the fourth and fifth lumbar vertebrae, with right pedicle effacement of L4. The tomography identified a lytic lesion, partially surrounded by sclerosis with a central nest of 3 centimeters in diameter located in the right pedicle with involvement of the transverse apophysis and reaction of the intertransverse space (Enneking 3). It was complemented by magnetic resonance and bone scintigraphy. The percutaneous biopsy guided by tomography yielded a diagnosis of osteoblastoma and foci of necrosis. A radical block resection was performed with clear tumor margins and instrumented stabilization. Results: After the surgical treatment, the patient evolved favorably, reversing the motor deficit. The anatomopathological study of the specimen confirms the preoperative diagnosis. Discussion: Intralesional resection may be an option in Enneking stage 2. In Enneking stage 3, a percutaneous diagnostic biopsy may be useful, and block resection is the preferred definitive treatment. Conclusions: The management of spinal osteoblastoma requires an exhaustive clinical-imaging analysis. Block resection with clear margins is preferred in advanced cases for management and to decrease the risk of recurrence. Level of Evidence IV; Case series ${ }^{h}$.
\end{abstract}

Keywords: Osteoblastoma; General surgery; Radionuclide imaging; Biopsy.

\section{RESUMO}

Objetivo: Apresentar caso clínico e atualizar bibliografia. Material e Método: Masculino, 24 anos de idade, consultado devido a lombociatalgia direita com três anos de evolução, com topografia L5 e déficit motor (M4). A radiografia mostra uma lesão radiopaca entre a quarta e a quinta vértebras lombares, com obliteração do pedículo direito de L4. A tomografia identifica uma lesão lítica parcialmente circundada por esclerose, com um ninho central de três centímetros de diâmetro localizado no pedículo direito com acometimento do processo transverso e reação do espaço intertransversário (Enneking 3). É complementado com ressonância magnética e cintilografia óssea, biópsia percutânea guiada por tomografia diagnóstica: osteoblastoma e focos de necrose. A ressecção radical foi realizada em bloco, com margens livres do tumor e estabilização instrumentada. Resultados: Após o tratamento cirúrgico o paciente evoluiu favoravelmente, revertendo o déficit motor. O estudo anatomopatológico da peça confirma o resultado pré-operatório. Discussão: A ressecção intralesional pode ser uma opção nos estágios de Enneking 2. Nos estágios de Enneking 3, uma biópsia diagnóstica percutânea pode ser útil e a ressecção em bloco é preferida como um tratamento definitivo. Conclusão: O manejo do osteoblastoma espinal requer uma análise clínica e imagética exaustiva. A ressecção de bloco com margens livres é preferida em casos avançados para o gerenciamento e para diminuir o risco de recorrência. Nível de Evidência IV; Série de casos ${ }^{h}$.

Descritores: Osteoblastoma; Cirurgia geral; Cintilografia; Biópsia.

\section{RESUMEN}

Objetivo: Presentar un caso clínico y actualizar bibliografía. Métodos: Un paciente de sexo masculino, 24 años de edad, buscó tratamiento para lumbociatalgia derecha de 3 años de evolución, con topografía L5 y déficit motor (M4). La radiografía mostró lesión radiopaca entre la cuarta y quinta vértebra lumbar, con borramiento pedicular derecho de L4. La tomografía identificó lesión lítica rodeada parcialmente de esclerosis, con nido central de 3 centímetros de diámetro ubicada en el pedículo derecho con afectación de la apófisis transversa y reacción del espacio intertransversario (Enneking 3). La tomografía fue complementada con resonancia magnética y gammagrafía ósea. La biopsia percutánea guiada por tomografía produjo diagnóstico de osteoblastoma y focos de necrosis. Se llevó a cabo la resección radical en bloque con márgenes libres del tumor y estabilización instrumentada. Resultados: Luego del tratamiento quirúrgico, el paciente ha evolucionado favorablemente, revirtiendo el déficit motor. El estudio anatomopatológico de la pieza confirma el diagnóstico preoperatorio. Discusión: La resección intralesional puede ser una opción en los estadios Enneking 2. En los estadios Enneking 3, puede ser útil la realización de una biopsia percutánea diagnostica, y como tratamiento definitivo se prefiere la resección en bloque. Conclusiones: El manejo del osteoblastoma espinal requiere un exhaustivo análisis clínico-imagenológico. La resección en bloque con márgenes libres es preferida en los casos avanzados para el manejo y disminuir el riesgo de recidivas. Nivel de Evidencia IV; Serie de casos'.

Descriptores: Osteoblastoma; Cirugía general; Cintigrafía; Biopsia. 


\section{INTRODUCTION}

Osteoblastoma $(\mathrm{OBL})$ is a rare benign primary bone tumor that produces primary bone and mainly affects the long bones. The incidence of $\mathrm{OBL}$ is low and the male to female ratio is $2: 1$. It accounts for $1 \%$ of all bone tumors and around $40 \%$ are located in the spine, most often involving the posterior elements. ${ }^{1-3}$ Histologically, they are indistinguishable from the smaller osteoid osteomas (OO). OBL is usually larger than $2 \mathrm{~cm}$ in diameter, while $O O$ is $1.5 \mathrm{~cm}$ or less. These primary bone cancers (PBC) tend to predominate in the pediatric population during the second decade of life..$^{2-3}$

Both $\mathrm{OBL}$ and $\mathrm{OO}$ can present a wide range of clinical manifestations. Between $15 \%$ and $25 \%$ of these tumors are locally aggressive or have the potential for malignant transformation. ${ }^{1}$

According to the literature, there are two types of OBL: conventional $\mathrm{OBL}(\mathrm{COBL})$ and aggressive $\mathrm{OBL}(\mathrm{AOBL})$. Radiographically, $\mathrm{AOBL}$ has a greater tendency to present lytic characteristics than its conventional counterpart. ${ }^{3}$

Surgical resection is the main treatment for spinal OBL, with high recurrence rates in subtotal resections. Some have proposed total resection (TR) for Enneking II tumors and block resections (BR) for Enneking III or AOBL variants. ${ }^{4}$ TRs are highly invasive, more technically difficult surgeries and are associated with high rates of morbidity and mortality. ${ }^{2,4}$

$\mathrm{BR}$ refers to the removal of the tumor in one piece. Other options are curettage $(\mathrm{CU})$ and fragmentary resection (FR), which refers to deliberate intralesion resection. ${ }^{2}$

The management of these PBCs requires a highly specialized multidisciplinary team. Surgery is considered a key element of their treatment. Achieving adequate margins is fundamental to improve survival and reduce local recurrence.

Here we present the case of a patient with $\mathrm{OBL}$ in $\mathrm{L} 4$ treated with $\mathrm{BR}$ and his follow-up for six months following surgery.

\section{METHODS}

We present the case of a male patient, 24 years of age, who sought treatment for right lumbosciatalgia of 3 years of evolution and authorized in writing the anonymous presentation of the case. Analysis by the Institutional Review Board was not necessary.

In the physical examination, he had low back pain radiating to the right lower limb (L4 region), with positive Lasègue's sign and M4 motor deficit.

In the X-ray, a radiopaque lesion was observed between the fourth and fifth vertebrae with diffuse borders and involvement of the intertransverse space. (Figure 1)

In the computed tomography, a lytic area surrounded by sclerosis with a central nest of 2 centimeters in diameter in the right pedicle of the fourth lumbar vertebra could be identified with expansion towards the surrounding soft tissue and irregular borders, compromising the right transverse apophysis and reaction of the intertransverse space. (Figure 2)

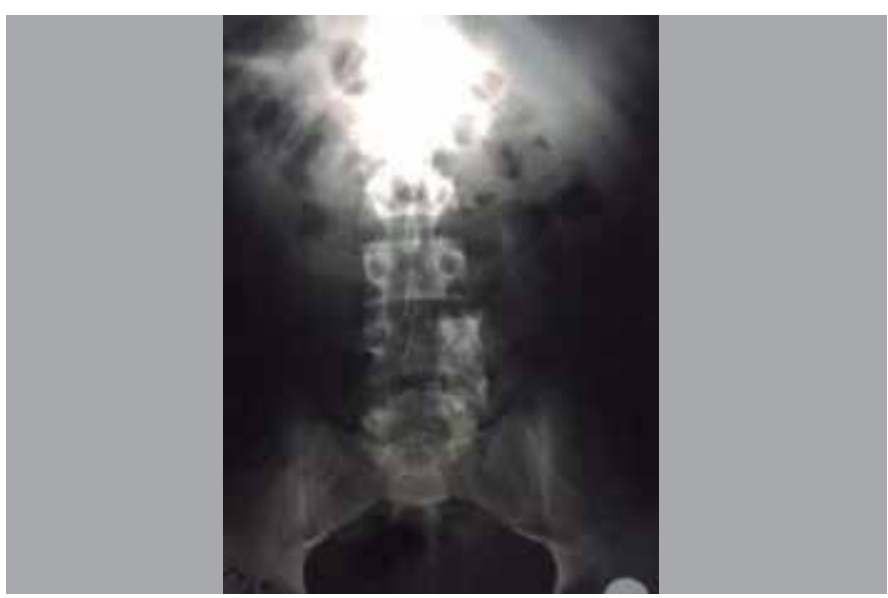

Figure 1. Front-view X-ray of the lumbar spine showing the lesion compromising the right pedicle of $\mathrm{L} 4$
Magnetic resonance imaging revealed edema of the paraspinal muscle planes and the ipsilateral psoas muscle. (Figure 3)

Scintigraphy was requested and indicated a region of hyper-uptake in the fourth lumbar vertebra.

With the imaging characteristics (infiltration of the soft tissue, diffuse borders, involvement of the intertransverse space), pointing to a suspected Enneking III lesion, it was decided that a percutaneous biopsy guided by tomography would be performed.

After six weeks, the pathology report was received with a diagnosis of osteoblastoma and foci of necrosis.

A block resection of the tumor was indicated, carefully following the path of the proximal insertion of the nerve root at that level.

\section{Surgical technique}

The patient, under general anesthesia, was positioned in ventral decubitus with thoraco-pelvic supports and ocular protection. The area was brushed and rubbed with chlorhexidine antiseptic solution. Sterile fields were placed and a posterior median incision was performed, exposing the lamina. After identifying the level under fluoroscopy, $6 \times 45 \mathrm{~mm}$ pedicle screws and rods were placed bilaterally in L3 and $\mathrm{L} 5$ and on the left in L4 with hands-free technique. A blunt dissection with gauze was performed, releasing the anterior aspect of the intertransverse space, and then a block resection of the tumor, using chisel and hammer and respecting the margins, was executed. (Figure 4)

The surgical site was flushed with abundant physiological solution, a drain was placed, and the wound was closed by planes.

The patient was sitting 48 hours following surgery and walking 72 hours following surgery.

\section{RESULTS}

Eight days after the block resection of the tumor, the left pedicle screw of $L 5$ had to be replaced to correct bad positioning. The

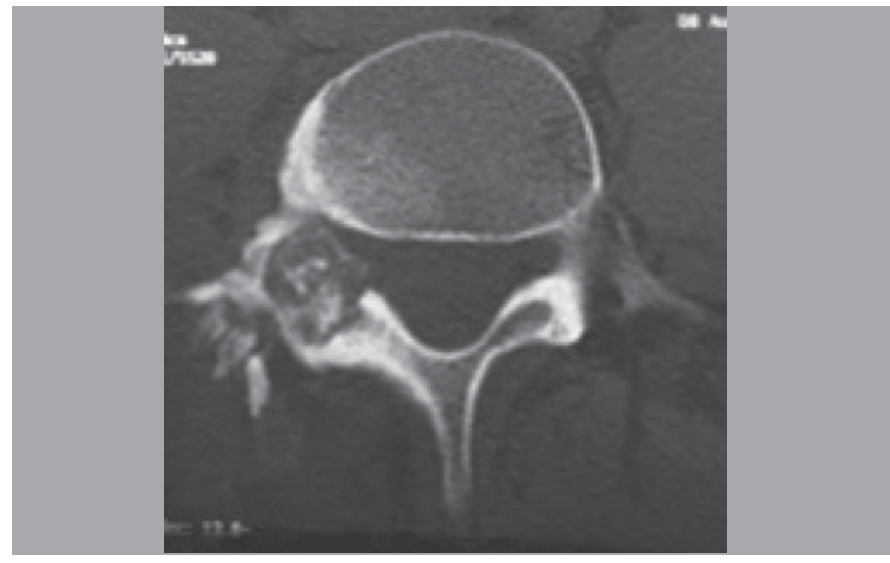

Figure 2. Tomography axial slice showing the lesion in the right posterior arch.

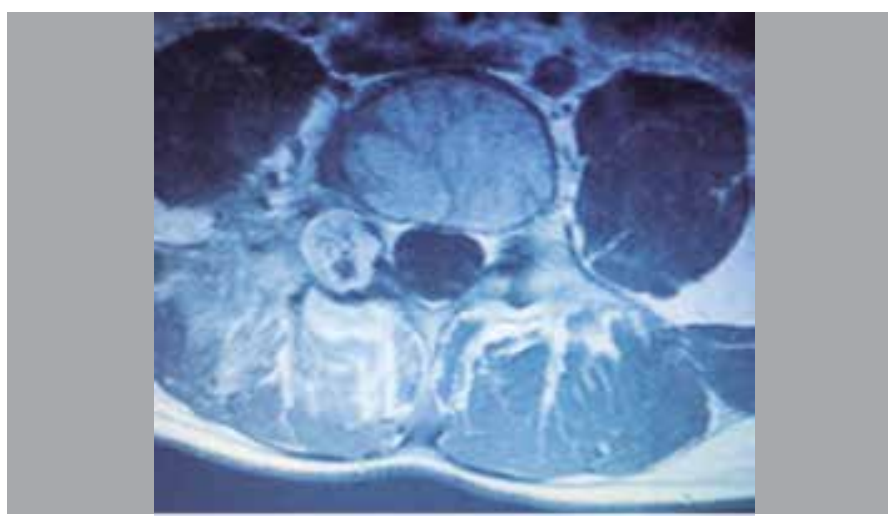

Figure 3. Magnetic resonance axial slice showing the lesion and its compromise of the soft tissues. 


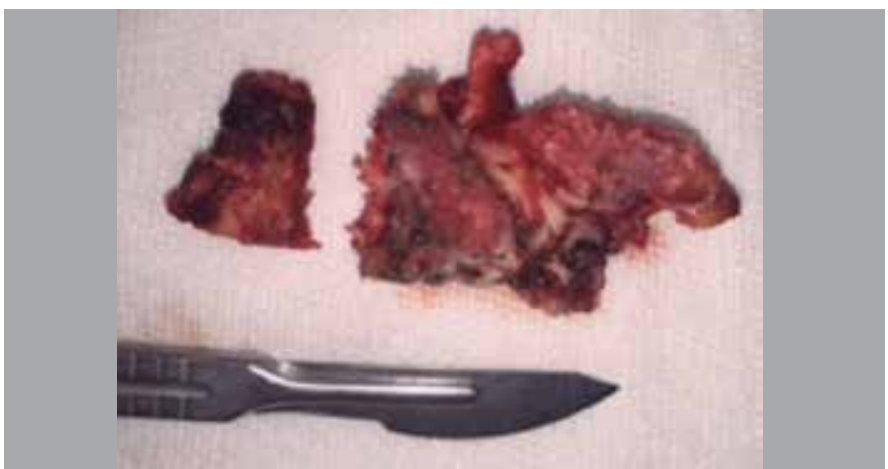

Figure 4. Image of the surgical specimen showing the block resection.

stitches were removed after 15 days and at 3 months following surgery, the motor deficit had been reversed.

At 7 weeks, the definitive results of the anatomopathological study of the block of bone were received and confirmed the preoperative diagnosis, indicating trabecular bone with signs of remodeling, foci of osteoblastoma, and areas of necrosis.

\section{DISCUSSION}

The Enneking system for stratification and characterization of benign bone tumors is used to define the OBL stages. The classification scheme is based on the radiographic tumor margins. The three stages of this system are defined as latent, active, and aggressive. Enneking stage II OBLs (active) show a combination of lytic and sclerotic changes with well-defined borders. They are similar to OOs, with lytic regions in the periphery of the ossified nucleus and they do not invade the surrounding soft tissues. Stage II lesions (aggressive) have predominantly osteolytic behavior. They erode the margins of the cortical bone and can enter the spinal canal and infiltrate the soft tissues. ${ }^{3}$

Fine needle puncture-aspiration can be used in the preoperative diagnosis. This diagnostic modality can be used for osteoblastomas and other spinal bone tumors. When epidural extension causes neurological deficit, puncture-aspiration enables early diagnosis. ${ }^{3}$

In a recent systematic review, Harrop ${ }^{5}$ found that the $\mathrm{AOBL}$ variant (Enneking III) is associated with a local recurrence rate greater than $50 \%$ following a $\mathrm{BR}$, while the $\mathrm{COBL}$ variant (Enneking II) has a recurrence rate between $10 \%$ and $15 \%$. In this review, FR can be strongly recommended for COBL (Enneking II), while $\mathrm{BR}$, when anatomically feasible, is highly recommended for AOBL (Enneking III). ${ }^{3}$

Collignon ${ }^{6}$ et al. reached similar conclusions in their work. For the treatment of $A O B L$ (EIII), a more aggressive strategy must be elected. A resection that attempts to remove a piece with tumor free margins should be the first treatment option. The risks of these more demanding procedures are justified due to the greater risk of recurrence and progression to malignancy with less aggressive treatments.
When anatomic limitations or tumor volume prevent the execution of a block resection with suitable margins, or when the patient refuses to risk the morbidity associated with the BR or is not clinically able to undergo this type of surgery, radiotherapy (RT) can be a good option. The use of adjuvant RT is also valuable in recurrent or incompletely resected lesions. ${ }^{1,3}$

Multiple studies have published quality of life (QOL) scores comparable to those of the normal population following block resection, with only a few of them reporting scores slightly lower than the general population. ${ }^{7}$ The "physical component" of these QOL scores is usually the one affected after block resection. This may be attributed to the resection of soft tissues (muscle, nerves) and complex reconstructions that result in deterioration of the spine. Improved QOL scores have been reported only after three years following surgery. ${ }^{7} \mathrm{As}$ is to be expected, QOL scores are lower in patients with active tumor load as compared to patients who are free from the disease.

Radiotherapy as a treatment for $\mathrm{OBL}$ is a controversial subject among the experts. It has been reported that RT may in fact be associated with late sarcomatous change and that it is a potentially ineffective therapeutic modality. ${ }^{3}$ Other authors have suggested its use as an adjuvant following intralesional curettage of EIII OBLs that may not be operable by block reesection. . $^{2,3}$

Even with an acceptable extent of the resection, recurrence rates are approximately $10 \%{ }^{3}$

There is controversy around whether spinal fusion should be performed following resection. The precise definition of spinal instability has not been clear in the literature, The Spinal Oncology Study Group (SOSG) defines spinal instability as "a loss of spinal integrity" resulting from a neoplastic process, associated with pain related to movement, symptomatic or progressive deformity, and/ or neural compromise under physiological loads. , $3,5,8$ The SOSG recently developed the SINS (Spinal Instability Neoplastic Score) as a method for identifying preoperative instability in spinal oncology. Although it was described and has been applied mainly to metastatic spine disease, several authors suggest its use as a guide for making decisions about whether or not fusion is needed. ${ }^{8}$

\section{CONCLUSIONS}

The management of spinal osteoblastoma requires an exhaustive clinical-imaging analysis

In cases where a benign Enneking II (active) tumor is suspected, it is possible to opt for intralesional resection and curettage.

In contrast, for stage III (aggressive) tumors, it may be useful to first perform a biopsy, carefully directing the route of the puncture, and then a block resection with free margins is suggested to manage the lesion and to reduce the risk of recurrence.

All authors declare no potential conflict of interest related to this article.

CONTRIBUTION OF THE AUTHORS: Each author made significant individual contributions to this manuscript. PLB (0000-0003-0060-6558) ${ }^{\star}$ developed the project plan, managed the bibliographical support and analysis of the results, and participated in the discussion of the conclusion and the editing of the final version. RAG (0000-0001-9489-5615)* worked on the bibliographical review and the technical details. RAG and EAC $(0000-0002-6113-5123)^{\star}$ participated in the discussion of the conclusions and the final draft. NMC (0000-0002-5851-2821)* worked on the technical details, the discussion of the conclusions, and the editing of the first draft. EAC contributed to the bibliographical review, imaging support, and creating the tables. AEB (0000-0002-5568-867X)* and MM (0000-0002-5281-5645)* participated in the discussion of the conclusion and the editing of the first draft. *ORCID (Open Researcher and Contributor ID).

\section{REFERENCES}

1. Boriani S, Amendola L, Bandiera S, Simoes CE, Alberghini M, Di Fiori M, et al. Staging and treatment of osteoblastoma in the mobile spine: a review of 51 cases. Eur Spine J. 2012;21(10):2003-10

2. Charest-Morin R, Dea N, Fisher CG. Health-Related Quality of Life After Spine Surgery for Primary BoneTumour. CurrTreat Options Oncol. 2016;17(2): 9.

3. Galgano MA, Goulart CR, Iwenofu H, Chin LS, LavelleW, Mendel E. Osteoblastomas of the spine: a comprehensive review. Neurosurg Focus. 2016;41(2):E4.

4. Elder BD, Goodwin CR, KosztowskiTA, Lo SF, Bydon A, Wolinsky JPK, et al. Surgical Management of Osteoblastoma of the Spine. Case Series and Review of the Literature. Turk Neurosurg. 2016;26(4):601-7.
5. Harrop JS, Schmidt MH, Boriani S, Shaffrey Cl. Aggressive "benign" primary spine neoplasms: osteoblastoma, aneurysmal bone cyst, and giant cell tumor. Spine (Phila $\mathrm{Pa}$ 1976). 2009:34(22 Suppl):S39-47.

6. Collignon JC, Kalangu K, Flandroy P. [Benign osteoblastoma of the spine. Apropos of 4 cases with a case of spontaneous recoveryl. Neurochirurgie. 1988; 34(4):262-70.

7. Fisher CG, Keynan O, Boyd MC, Dvorak MF. The surgical management of primary tumors of the spine: initial results of an ongoing prospective cohort study. Spine. 2005;30(16):1899-908.

8. Li Z, ZhaoY, Hou S, Mao N, Yu S, HouT. Clinical Features and Surgical Management of Spinal Osteoblastoma: A Retrospective Study in 18 Cases. PLoS One. 2013;8(9):e74635. 